\title{
The Challenges and Opportunities of Ideological and Political Education Work Under the New Media Perspective
}

\author{
Wei-zhong Zhao \\ Humanities and Social Science of \\ Agricultural University of Hebei, \\ Baoding, China
}

\author{
Li Gao \\ College Students' entrepreneurship education and service \\ center of \\ Agricultural University of Hebei, \\ Baoding, China
}

\begin{abstract}
With the development of new media technology, mobile phones and Internet are highly popularized in colleges and universities. The development of new media has brought not only opportunities but also severe challenges to ideological and political education work in universities. The application of new media has become the important proposition in the field of ideological and political education. This paper will analyze the challenges and opportunities the ideological and political education faces under the new media perspective, and put forward the relevant reform measures, which have a great significance to improve the effectiveness of colleges' ideological and political education work.
\end{abstract}

Keywords: new media; colleges and universities; ideological and political education; challenges and opportunities.

\section{INTRODUCTION}

With the changing of digital information technology and the rapid development of Internet technology, new media's effect increases every day in people's work, study and daily life ${ }^{[1]}$. College students are the direct users of new media. New media has become the important form of interpersonal communication and expressing personal will. Meanwhile, new media has also become an important channel and window for college students showing their talents and personality. The most obvious feature of the new media is quick and massive information transmission, and frequent update. New media contains a lot of unfiltered information intermingled with good and bad information, which has a harmful effect on the college students. Colleges take the responsibility of cultivating students' professional skills, ideological and political quality and volitional quality ${ }^{[2]}$. The emergence and popularization of new media change the ideological and political education environment. But in the new media era, colleges' ideological and political education faces some challenges and opportunities ${ }^{[3]}$. How to improve the new media's effectiveness in colleges' ideological and political education work is an importance research content. Under the perspective of new media, this paper will analyze the challenges and opportunities that colleges' ideological and political education work faces, and put forward the corresponding reform measures, hoping to improve its effectiveness.

\section{New media and ideological and political education.}

\subsection{The basic meaning of new media.}

New media is the fifth media to spread information by digital new technology, such as Internet, mobile, etc, which is based on the four traditional media. The four traditional media refers to newspaper, outdoor, radio and television. New media can be divided into two main categories. One is network media based on computer hardware equipment, such as QQ, micro-blog, BBS, academic websites. The other one is mobile digital media based on mobile phone, such as micro letter, mobile news, mobile phone magazine, fetion, etc ${ }^{[1-2]}$.

\subsection{The basic meaning of ideological and political education.}

Ideological and political education is a kind of social practice activities that, a certain class, political parties, social groups make people accord with the ideological and moral demanded by certain society and certain class. Ideological and political education follows the law of development of people ideology and moral character reforming, with certain ideology, political views, and moral role, which have a purpose, planned and organized influence on its members ${ }^{[5]}$.

\subsection{The new media influences on ideological and political education.}

With the rapid development of modern science and technology and continuously improving of the new media technology, new media increasingly impact on people's social life, and is unknowingly changing people's living habits and working. As a communication carrier, this emerging media increasingly influence on colleges' ideological and political education. The new media can be regarded as a factor in ideological and political education system, or a factor in the social environment. 


\section{The challenge of colleges' ideological and political education work.}

\subsection{The new media brings adverse effects on college students' ideological and political work.}

In recent years, as the most idea active group, college students pay more and more attention to micro-blog, blog, etc. Throughout the new media's development and changes in our county, we can see that new media play a positive role in proving the development and prosperity of socialist culture, spreading mainstream values. As the ideological and political workers, we should soberly realize that there are different kinds of "voives" in new media-information of diversified values and negative, such as disseminating bawdy and pornography information trough $\mathrm{QQ}$, releasing anti-party and anti-state comments and articles through blog, and spreading inflammatory gathering information through micro-blog. These ways and information will have a profound impact on students who have poor self-control, lack of social experience, and have weaker discrimination. These are also bad for college students to form correct outlook on life, world outlook, and value, then affect the stability and harmonious development of society.

3.2. The new media easily cause college students' psychological healthy problems.

As is known to all that, new media attract students by its novel visual expression and rich content. But over obsession may break the balance of study and life, and thus trigger a series of college students' mental health problems, such as interpersonal obstacles. Since new media has great virtuality and inauthenticity, students can realize the idea by that can't come true in real life, which greatly satisfy parts introverted students' self gratification. These satisfactions make them addicted to it, and unable to extricate themselves. But network is not reality, virtual network and cruel reality will often cause huge contrast, and cause students' psychological problems. Therefore, these problems caused by new media worth ideological education workers' thinking.

\subsection{The new media brings students interpersonal obstacles.}

Compared with the traditional communication means, new media means, such as text, micro letter, QQ, micro-blog, BBS, etc, are all in the space of virtual human-machine interaction, resulting in some students addicted to virtual communication environment. These students are indifference to real interpersonal communication, which lead students strained and withdrawn. Finally, these students may have psychological tendency of escaping from reality, and have communication barriers in real life.
4. The opportunities of colleges' ideological and political education work.

\subsection{The new media provides open and equal communication platform.}

As is known to all, the new media is a multi-media interactive platform with open and rich information. It is not only a tool and carrier to obtain information, but also a communication platform. In this platform, people can realize point-to-point and point-to-surface's communication, also realize public or private communication through QQ, micro-blog, renren, etc. College students can understand information, communicate emotion, and enhance communication through mobile phones, computers and other carriers anywhere and anytime. It is an important platform for college students' ideological and political education work to play its role better and implement education communication.

\subsection{The new media shortens the communication gap between teachers and students.}

Taking advantage of new media, teachers can easily know students' living and study status, understand students' thought trend by adding attention, and go deep into students. If teachers know what the students think, the ideological and political education work can be carried out yield twice the result with half the effort. With the development of network, students like and get used to communicate with network language. These web terms are not only liked by young people, but also can close the distance between people. If teachers use the communication that students like in ideological and political education work, students can easily understand, and cooperate with teaching.

4.3. The equality of new media is more advantageous to ideological and political education's construction.

New media break the boundaries between real and virtual space, making the relationship between the students and teachers more equal. In the past education teaching work, there is a certain inequality, making the students not dare to tell the truth, or hide their real thoughts. But using the new media, not only the teachers can understand students' personality and lifestyle by students' daily dynamic, but also the students can have in-depth knowledge of teachers. This makes the teachers no longer mysterious, and quickly pulls close the distance between teachers and students, which makes ideological and political education work more convenient. 


\section{The reform measures of colleges' ideological and} political education under the new media perspective.

\subsection{Enhance the education workers' media literacy and strengthen the teams' construction.}

In order to give full play to ideological and political education function of the new media and complete ideological and political education work using the new media, the construction of ideological and political teams should be strengthened. Only by training ideological and political education workers and improving their media literacy, can we play the new media's education function better. On one hand, strengthen the technical training about the media, and improve education workers' application ability of new media. On the other hand, education workers have to learn communication knowledge and mastery communication skills. In the information age, the ideological and political education worker should use the transmission characteristics of new media to spread information, which can improve the efficiency of ideological and political education work.

\subsection{Improve the students' analytical and resolving ability to network information.}

Students' media literacy refers to the response ability when people in the face of kinds of media information. This response ability refers to analysis, understanding, choice, query, evaluation, etc. In the new media environment, facing with all kinds of complex and complicated media information, students often lack enough warning and analysis judgment ability, leading the students' values and self cognitive ability chaos. Colleges shall offer the courses related with media literacy, such as cultivation education, and put it into the scope of ideological and political education work. They can also make full use of campus media platform to build media literacy's learning and training platform, which can increase the propaganda and popularization of media literacy. In addition, education workers can carry out discuss work about social hot spot and focus of network information, guiding students to interpret the media information correctly. This way can also improve and train the students' judgment and discrimination for media information, so that they can use all kinds of new media resources reasonably and regularly.

\subsection{Build up a positive new media campus cultural environment.}

In the recent new media environment, emerging media has formed a kind of culture. So colleges have to put the new media culture into the campus cultural overall construction layout, enriching and cultivating campus cultural mode and content on the basis of traditional campus culture construction. At the same time, colleges should make full use of education function of campus culture to grasp the initiative of ideological and political education work. Colleges should build a website platform to make full use of new media's advantages, mastering the active voice and establishing the authority of the mainstream campus culture. Since the students are the frequent users of mobile phone, colleges should strengthen the cooperation with communication companies to set up positive campus SMS service platform. Colleges can also strengthen the interaction and communication with students by media means, such as radio, television, mobile news, etc. Finally, colleges should establish objective, comprehensive and timely new media monitoring.

\subsection{Establish perfect regulatory system and improve} the effectiveness ideological and political education.

For the ideological and political education's regulation, the principle is effectiveness, and appropriate to avoid students' resistance. The purpose of regulation is to make educates get better ideological and political education through new media.

(1) Colleges can call for influential, responsibility, determination educates, paying attention to popular nowadays, popular network news and rumors timely. Some extreme and bewitch information should be timely feedback to the relevant regulatory authorities, and persuade lost students positive.

(2) Colleges can cultivate professional and technical personnel in the center of the campus network culture, tracking IP address that spread bad information, reporting to regulators, and processing these things according to relevant regulations.

(3) Regulatory must rely on the professional and technical titles of national network security department. Since the new media technology has the characteristics of wide spread surface, high content of science, quick propagation speed and concealment, some reactionary personnel may use new media to spread negative information. Relying on the professional technology of national network security department is a effective shortcut to implement efficient network supervision.

\section{Conclusion}

With the continuous development and innovation of new media technology, college ideological and political education work is facing many challenges and opportunities. Colleges should study and analyze the characteristics of new media, and the relationship between new media and ideological and political education work, then use the new media reasonably, and improve the implementation effect. 


\section{References}

[1] Guo Huiyi. The research on ideological and political education's reform and innovation under the new media era. Jilin agricultural university,2014.

[2] Xu Haixin, Liao Haojun. Analysis of how to play a effective role in college students' ideological and political education. Academic Forum, 2011,34(7):193198.
[3] Li Zhongxin. Research on college ideological and political education method under the background of new media. Industrial \&Science Tribune, 2014,13:091.

[4] Ouyang Lijun. On the challenges and solutions of college ideological and political education in new media environment. Science tribune, 2013(25):64-65.

[5] Yang Wanbo, Zhang Yaocan. Ideological and political education principle. Beijing: Higher education press, 2010. 